\title{
KARAKTERISTIK KONSELOR PADA CALON KONSELOR BERDASARKAN PERBEDAAN KELOMPOK GENDER
}

\author{
Shinta Mayasari \\ Program Studi Bimbingan Konseling Universitas Lampung, email: shintapsy@yahoo.com

\begin{abstract}
COUNSELOR CHARACTERISTIC AMONG CANDIDATED COUNSELOR BASED ON GENDER GROUP DIFFERENCES
\end{abstract}

A qualified counselor will determine the success of the counseling process. Three characteristics are needed and determine the quality of a counselor, namely: (1) congruence (authentic), (2) unconditional positive regard (acceptance), and (3) empathy (empathy). This study aims to describe the characteristics of counselors based on gender groups. The research sample consisted of 68 prospective counselor students who were divided into gender groups. The measuring instrument uses a counselor characteristic test developed using controversial statements with alternative Likert scale answers. The results of the study found that there were significant differences in the characteristics of counselors among students of the guidance and counseling study program based on differences in gender groups. There is a significant difference between the need to develop educational programs and effective counselor training for male and female students. The development of congruence characteristics is more needed for male students, while female students on the characteristics of unconditional positive regard. A larger sample size is needed to increase heterogeneity, and additional interviews are conducted individually to deepen the discussion.

Key words: counselor characteristics, gender, measurement of emphaty, psychological instrument.

Konselor yang berkualitas akan menentukan keberhasilan proses konseling. Tiga karakteristik yang diperlukan dan menentukan kualitas konselor, yaitu: (1) congruence (otentik), (2) unconditional positive regard (penerimaan), dan (3) empathy (empati). Penelitian ini bertujuan untuk melihat gambaran karakteristik konselor berdasarkan kelompok gender. Sampel penelitian merupakan 68 mahasiswa calon konselor yang dibagi berdasarkan kelompok gender. Alat ukur menggunakan tes karakteristik konselor yang dikembangkan dengan menggunakan pernyataan kontroversial dengan alternatif jawaban skala Likert. Hasil penelitian menemukan ada perbedaan yang signifikan dalam karakteristik konselor pada mahasiswa program studi bimbingan dan konseling berdasarkan perbedaan kelompok gender. Ada perbedaan yang signifikan antara kebutuhan pengembangan program pendidikan dan pelatihan konselor yang efektif bagi mahasiswa laki-laki dan perempuan. Pengembangan karakteristik congruence lebih dibutuhkan untuk mahasiswa laki-laki, sementara mahasiswa perempuan pada karakteristik unconditional positive regard. Jumlah sampel yang lebih besar diperlukan untuk meningkatkan heterogenitas, dan melakukan wawancara tambahan secara individual untuk memperdalam diskusi.

Kata kunci: karakteristik konselor, gender, pengukuran empati, instrumen psikologi.

\section{PENDAHULUAN}

Konseling adalah salah satu bentuk hubungan membantu. Bantuan yang diberikan bukan hanya sekedar membantu, tetapi melibatkan tenaga, waktu, pikiran, dan perasaan si "pembantu" (konselor). Idealnya konselor adalah orang yang mendapatkan pendidikan untuk melakukan konseling dan melalui proses sertifikasi serta harus mendapatkan lisensi untuk melakukan konseling (Gladding, dalam Lesmana, 2005). Dengan demikian diharapkan ia dapat memberikan bantuan secara 


\section{KARAKTERISTIK KONSELOR PADA CALON KONSELOR BERDASARKAN KELOMPOK GENDER}

profesional. Konselor yang berkualitas sangat menentukan keberhasilan konseling. Kualitas konselor meliputi karakteristik (psikologis), pengetahuan teknis, dan keterampilan dalam melakukan konseling. Sejumlah penelitian (dalam Lesmana 2005; Rogers, 2017) menyimpulkan bahwa di antara ketiga kualitas ini, karakteristik konselor lah yang lebih mempengaruhi efektivitas konseling.

Tinjauan terhadap sejumlah literatur menemukan bahwa salah satu teori konseling yang membahas secara mendalam mengenai karakteristik konselor yang efektif adalah clientcentered counseling (person-centered counseling) yang dipelopori oleh Carl Rogers. Teori ini kemudian banyak diaplikasikan untuk pendekatan kelompok, keluarga, masyarakat, dan individual (Lesmana, 2005). Konselor dalam client-centered counseling, menggunakan diri sendiri sebagai instrumen perubahan bagi klien. Untuk memfasilitasi perubahan klien, ada tiga karakteristik yang perlu dan sudah cukup untuk dimiliki konselor, yaitu (1) congruence, (2) unconditional positive regard, dan (3) empathy (Rogers, 2017). Setiap karakteristik memiliki keterkaitan yang erat satu sama lain (Corsini \& Wedding, 2010).

Kompetensi konselor sekolah yang tertuang dalam Peraturan Menteri Pendidikan Nasional Republik Indonesia mensyaratkan adanya empat kompetensi, yaitu: pedagogik, kepribadian, sosial dan profesional (2008). Dalam aspek kepribadian Program Studi Bimbingan dan Konseling Fakultas Keguruan dan IImu Pendidikan Universitas Lampung
(PSBK FKIP Unila) menitikberatkan pengembangan karakteristik congruence (otentik) dan empathy (empati) melalui perumusan misi yang salah satunya adalah menyelenggarakan pendidikan unggul untuk menghasilkan calon konselor sekolah yang empatik, autentik, dan kreatif (2015).

Karakteristik otentik dan empati merupakan salah satu aspek kepribadian yang dikembangkan oleh PSBK FKIP Unila untuk mempersiapkan mahasiswa menjadi konselor sekolah yang profesional sesuai dengan standar nasional. Karakteristik otentik dan empati yang dikemukakan Rogers merupakan syarat yang sangat penting bagi individu yang menjalankan profesi sebagai konselor. Oleh karena itu, peneliti ingin melihat bagaimana karakteristik konselor mahasiswa PSBK Unila berdasarkan perbedaan gender. "Apakah terdapat perbedaan yang signifikan dalam karakteristik konselor terhadap kelompok jender mahasiswa laki-laki dan perempuan di PSBK Unila?". Informasi yang diperoleh dari penelitian ini akan menjadi dasar dalam menyusun program pengembangan kepribadian bagi mahasiswa PSBK Unila.

\section{Teori Karakteristik Konselor}

Konseling merupakan bagian dari helping relationship (hubungan membantu). Hubungan membantu merupakan bentuk hubungan yang menyediakan kondisi untuk individu agar dapat memenuhi kebutuhan untuk hidup berarti, mempunyai rasa aman, kebutuhan untuk cinta dan respek, harga diri, dapat membuat keputusan dan aktualisasi diri

Shinta Mayasari, Program Studi Bimbingan Konseling Fakultas Keguruan dan Ilmu Pendidikan Universitas Lampung. Email: shintapsy@yahoo.com 


\section{KARAKTERISTIK KONSELOR PADA CALON KONSELOR BERDASARKAN KELOMPOK GENDER}

(Lesmana, 2005). Carl Rogers (dalam Lesmana, 2005), salah seorang tokoh besar di bidang konseling, mengartikan konseling sebagai suatu hubungan di mana sedikitnya satu dari pihak yang terkait mempunyai tujuan untuk meningkatkan pertumbuhan, perkembangan, kedewasaan, dan juga peningkatan fungsi serta kemampuan untuk menghadapi hidup yang lebih baik dari pihak yang lain itu.

Istilah konseling sering bertumpang tindih dengan istilah lain yaitu psikoterapi. Beberapa tokoh, misalnya Gladding (dalam Lesmana, 2005) mengungkapkan bahwa konseling digunakan untuk kasus-kasus "normal"; sedangkan psikoterapi untuk kasuskasus yang berkaitan dengan gangguan jiwa serius. Rogers sendiri tidak membedakan istilah konseling dan psikoterapi. Dalam Counseling and Psychotherapy, ia mengungkapkan:

These terms (Counseling and Psychotherapy) will be used more or less interchangeably ........ because they are seem to refer to the same basic method - a series of direct contacts with the individual which aims to offer him assistance in changing his attitudes and behavior (Rogers, 2007:1).

Menurutnya, istilah konseling dan psikoterapi merujuk pada metode dasar yang sama, yaitu serangkaian kontak langsung dengan individu yang bertujuan membimbing perubahan sikap dan perilaku individu yang bersangkutan. Kegiatan konseling dapat dilakukan oleh berbagai profesi. Misalnya social worker, psikiater, psikolog, guru, konselor perusahaan, dan sebagainya (Rogers, 2007).
Individu dari bidang pekerjaan apapun yang melakukan konseling disebut sebagai konselor.

Kualitas konselor merupakan salah satu faktor penentu keberhasilan konseling. Faktor lainnya adalah struktur konseling, inisiatif klien, setting fisik, dan kualitas klien (Gladding, dalam Lesmana, 2005). Kualitas konselor meliputi karakteristik (psikologis), pengetahuan teknis, dan keterampilan dalam melakukan konseling. Efektivitas konseling umumnya lebih ditentukan oleh karakteristik konselor ketimbang pengetahuan teknis maupun keterampilan yang bisa dipelajari (Rogers, 2017).

Karakteristik konselor adalah atributatribut berupa kecenderungan konselor yang harus tampil (dalam bentuk tingkah laku) demi keberhasilan proses konseling (Rogers, 2017). Karakteristik ini berakar pada nilai, yaitu himpunan pandangan, pendapat, dugaan, dan keyakinan seseorang, baik tentang dirinya sendiri maupun tentang lingkungannya. $\mathrm{Di}$ dalam nilai terdapat keyakinan seseorang tentang perlu-tidaknya melakukan hal tertentu, benar-salahnya pendapat tertentu, baikburuknya hal tertentu, dsb.

Rogers (2017) menyebutkan tiga karakteristik utama konselor yang efektif. Ketiga karakteristik yang dimaksud adalah congruence, unconditional positive regards, dan empathy. Ketiga karakteristik ini memiliki keterkaitan yang erat, seperti yang dikutip dari gagasan Rogers:

"In the first place, the therapist must achieve a strong, accurate empathy. But such deep sensitivity to moment-to-moment "being" of another person requires that the therapist first accept, and to some

Shinta Mayasari, Program Studi Bimbingan Konseling Fakultas Keguruan dan Ilmu Pendidikan Universitas Lampung. Email: shintapsy@yahoo.com 


\section{KARAKTERISTIK KONSELOR PADA CALON KONSELOR BERDASARKAN KELOMPOK GENDER}

degree prize, the other person. That is to say, a sufficiently strong empathy can scarcely exist without a considerable degree of unconditional positive regard. However, since neither of this conditions can possibly be meaningful in the relationship unless they are real, the therapist must be, both in this respects and in others, integrated and genuine within the therapeutic encounter." (Corsini \& Wedding, 2010:143)

Secara ringkas, Lesmana (2005) menyimpulkan bahwa congruence adalah pemahaman mengenai dirinya sendiri dimana pikiran, perasaan dan pengalaman haruslah serasi. Dalam congruence, seseorang harus memahami bias-bias yang ada di dalam dirinya, prasangka-prasangka yang mewarnai pikirannya, harus mengetahui kelemahan dan aset-aset yang dipunyainya sehingga dapat membuat pembedaan antara dirinya dan orang lain.

Sedangkan unconditional positive regards adalah penerimaan tanpa syarat atau respek yang harus ditunjukkan oleh seorang konselor kepada kliennya. la harus dapat menerima bahwa orang-orang yang dihadapinya mempunyai nilai-nilai sendiri, kebutuhankebutuhan sendiri yang lain daripada yang dimiliki olehnya.

Mengenai empathy, Lesmana (2005) menyatakan bahwa empathy adalah memahami orang lain dari sudut kerangka berpikir orang lain tersebut. Empathy yang dirasakan harus juga diekspresikan, dan orang yang melakukan empathy harus orang yang "kuat", ia harus dapat menyingkirkan nilai-nilainya sendiri tetapi ia tidak boleh terlarut di dalam nilai-nilai orang lain.

Perlu diketahui bahwa ketiga karakteristik yang dikemukakan Rogers hampir selalu ditemukan dalam tulisan-tulisan lain yang membahas tentang karakteristik konselor. Hackney dan Cormier (dalam Lesmana, 2005) misalnya, mengungkapkan bahwa konselor seharusnya memiliki kesadaran tentang diri sendiri dan pemahaman diri, kesehatan psikologis yang baik, sensitivitas dan pemahaman tentang faktor-faktor rasial, etnik, dan budaya, keterbukaan, objektivitas, kompetensi, dapat dipercaya, dan interpersonal attractiveness. Sebagian dari karakteristik tersebut adalah penjabaran dari ketiga karakteristik konselor menurut Rogers, sehingga dalam penjelasannya tidak dapat dilepaskan dari konsep Rogers (Lesmana, 2005).

\section{Teori Gender}

Kategorisasi perempuan dan laki-laki didasarkan pada dua konsep yang sering dipertukarkan yaitu sex (diterjemahkan sebagai jenis kelamin atau seks) dan gender yang diperkenalkan tahun 1955 oleh John Money (dalam Mayasari 2005). Jender berasal dari Bahasa Inggris 'gender' yang berarti jenis kelamin, tetapi tidak sama dengan arti 'sex'. Jender secara umum digunakan untuk mengidentifikasi perbedaan perempuan dan laki-laki dari segi sosial, budaya, psikologis, dan aspek-aspek non-biologis lainnya. Sementara itu sex secara umum digunakan untuk

Shinta Mayasari, Program Studi Bimbingan Konseling Fakultas Keguruan dan Ilmu Pendidikan Universitas Lampung. Email: shintapsy@yahoo.com 


\section{KARAKTERISTIK KONSELOR PADA CALON KONSELOR BERDASARKAN KELOMPOK GENDER}

mengidentifikasi perbedaan perempuan dan laki-laki dari segi anatomi atau biologis.

Dalam ilmu psikologi, kontroversi operasionalisasi konsep jenis kelamin dan jender berpusat pada isu nature (alamiah, bawaan, biologis) vs nurture (belajar, pengalaman, sosial) dalam membentuk perbedaan perempuan dan laki-laki (Papalia, Olds, \& Feldman, 2007). Banyak ahli psikologi menggunakan jenis kelamin sebagai istilah biologis bagi komposisi genetik, anatomi, serta fungsi reproduksi primer dan sekunder, dan mengambil posisi interaksionis dalam mendefinisikan jender sebagai makna yang diberikan oleh individu dan lingkungan terhadap kategori biologis jenis kelamin.

Dari uraian tersebut dapat disimpulkan bahwa jender adalah suatu konsep yang digunakan untuk mengidentifikasi perbedaan perempuan dan laki-laki yang dilihat dari sudut non-biologis atau dari segi sosial budaya dan psikologis.

\section{METODE}

Pendekatan yang digunakan dalam penelitian ini adalah pendekatan eksplanatif untuk menguji hipotesis dan menjawab permasalahan utama penelitian. Variabel bebas adalah kelompok jender (laki-laki dan perempuan) dengan data berbentuk nominal. Variabel terikat adalah skor karakteristik empati yang diukur melalui tes karakteristik konselor dengan data berbentuk nominal. Tes karakteristik konselor dikembangkan oleh peneliti (Mayasari, 2013) dengan menggunakan pernyataan kontroversial (Tim Peneliti Fakultas Psikologi Universitas Indonesia, 2016) dengan alternatif jawaban skala Likert (Azwar, 2014).

Kriteria subjek penelitian adalah mahasiswa program studi bimbingan dan konseling. Subjek penelitian sebanyak 68 orang terdiri dari 34 mahasiswa laki-laki dan 34 mahasiswa perempuan. Teknik sampling tergolong non probability sampling karena tidak seluruh anggota populasi mendapat kesempatan yang sama untuk terpilih menjadi subjek penelitian (Anastasi \& Urbina, 1997) dan penarikan sampel dilakukan dengan teknik incidental sampling yaitu mengambil subjek yang paling tersedia asalkan memenuhi kriteria dan bersedia berpartisipasi (Kerlinger, 1992).

Metode statistik yang digunakan adalah statistik non parametrik, karena data berbentuk nominal (Crocker \& Algina, 2008). Teknik analisis yang digunakan yaitu rumus chi-square, karena data skor karakteristik konselor dikelompokkan berdasarkan frekuensi (Azwar, 2015). Hasil perhitungan diuji signifikansinya untuk melihat perbedaan skor karakteristik konselor antara kelompok jender laki-laki dan perempuan.

Shinta Mayasari, Program Studi Bimbingan Konseling Fakultas Keguruan dan Ilmu Pendidikan Universitas Lampung. Email: shintapsy@yahoo.com 


\section{KARAKTERISTIK KONSELOR PADA CALON KONSELOR BERDASARKAN KELOMPOK GENDER}

HASIL

Untuk menjawab permasalahan penelitian, skor karakteristik konselor subjek penelitian dikelompokkan menjadi tiga, yaitu congruence, unconditional positive regard, dan empathy. Untuk menjawab permasalahan penelitian, terlebih dahulu disajikan data yang memuat skor karakteristik konselor terhadap kelompok jender laki-laki pada tabel 1.

Tabel 1

Karakteristik konselor pada kelompok jender laki-laki

\begin{tabular}{ccccccccc}
\hline \multirow{3}{*}{ Jender } & \multicolumn{5}{c}{ Karakteristik konselor } & \multirow{2}{*}{ Jumlah total } \\
\cline { 2 - 7 } & \multicolumn{2}{c}{ Congruence } & $\begin{array}{c}\text { Unconditional positive } \\
\text { regard }\end{array}$ & \multicolumn{2}{c}{ Empathy } & & \\
\cline { 2 - 7 } & $\mathrm{N}$ & $\%$ & $\mathrm{~N}$ & $\%$ & $\mathrm{~N}$ & $\%$ & $\mathrm{~N}$ & $\%$ \\
\hline Laki-laki & 1 & 2,9 & 26 & 76,5 & 7 & 20,6 & 34 & 100 \\
\hline
\end{tabular}

Pada tabel 1 terlihat mayoritas mahasiswa laki-laki, yaitu sebanyak $76.5 \%$ memiliki karakteristik unconditional positive regard; sebagian kecil, yaitu 20.6\% memiliki karakteristik empathy, sementara hanya $2.9 \%$ yang memiliki karakteristik congruence. Dari data tersebut dapat disimpulkan bahwa sebagian besar mahasiswa laki-laki memiliki karakteristik unconditional positive regard yang dominan pada dirinya. Selanjutnya disajikan data yang memuat skor karakteristik konselor pada kelompok jender perempuan dalam tabel 2.

\section{Tabel 2}

Karakteristik konselor pada kelompok jender perempuan

\begin{tabular}{ccccccccc}
\hline \multirow{3}{*}{ Jender } & \multicolumn{9}{c}{ Karakteristik konselor } & \multirow{2}{*}{ Jumlah total } \\
\cline { 2 - 8 } & \multicolumn{2}{c}{ Congruence } & $\begin{array}{c}\text { Unconditional positive } \\
\text { regard }\end{array}$ & \multicolumn{2}{c}{ Empathy } & & \\
\cline { 2 - 8 } & $\mathrm{N}$ & $\%$ & $\mathrm{~N}$ & $\%$ & $\mathrm{~N}$ & $\%$ & $\mathrm{~N}$ & $\%$ \\
\hline Perempuan & 16 & 47,1 & 1 & 2,9 & 17 & 50 & 34 & 100 \\
\hline
\end{tabular}

Data pada tabel 2 menunjukkan bahwa sebagian mahasiswa perempuan, yaitu sebanyak $50 \%$ memiliki karakteristik empathy; sebagian lagi, yaitu $47.1 \%$ memiliki karakteristik congruence, sementara hanya $2.9 \%$ yang memiliki karakteristik unconditional positive regard. Dari data ini dapat disimpulkan bahwa sebagian mahasiswa perempuan memiliki karakteristik empathy yang dominan pada dirinya, dan sebagian lainnya (dalam jumlah yang kurang lebih sama) memiliki karakteristik congruence. Untuk menguji perbedaan karakteristik konselor terhadap kelompok jender laki-laki dan perempuan, ditampilkan pada tabel 3 .

Shinta Mayasari, Program Studi Bimbingan Konseling Fakultas Keguruan dan Ilmu Pendidikan Universitas Lampung. Email: shintapsy@yahoo.com 


\section{KARAKTERISTIK KONSELOR PADA CALON KONSELOR BERDASARKAN KELOMPOK GENDER}

\section{Tabel 3}

\section{Perbedaan karakteristik konselor pada laki-laki dan perempuan}

\begin{tabular}{lccc}
\hline & Value & df & $p$ \\
\hline Pearson Chi-Square & 40,550 & 2 &, 000 \\
\hline
\end{tabular}

Dari tabel 3 terlihat bahwa terdapat perbedaan yang signifikan antara karakteristik konselor pada mahasiswa laki-laki dan perempuan $\left(X^{2}(2, N=68)=40.550, p<.01\right)$.

\section{DISKUSI}

Secara umum, hasil penelitian menunjukkan ada perbedaan signifikan pada karakteristik konselor antara kelompok jender laki-laki dan perempuan. Pada kelompok jender laki-laki, mayoritas responden memiliki karakteristik unconditional positive regard sebagai karakteristik yang dominan mereka miliki. Bila dikaitkan dengan kebutuhan dasar pada manusia akan cinta, kehangatan, penerimaan dan penghargaan dari orang lain. Individu yang di masa kecilnya menerima rasa cinta tanpa syarat (unconditional positive regard) cenderung akan mengembangkan penghargaan positif bagi dirinya (Rogers, 2017). Tingginya karakteristik unconditional positive regard pada kelompok jender laki-laki berbanding terbalik dengan kelompok jender perempuan. Hanya $2,9 \%$ responden dari kelompok jender perempuan yang memiliki karakteristik unconditional positive regard yang dominan pada dirinya. Hal ini mengindikasikan bahwa kebutuhan akan cinta, kehangatan, penerimaan dan penghargaan pada mayoritas responden kelompok jender perempuan kurang terpenuhi. Akibatnya mayoritas kelompok jender perempuan cenderung mengembangkan penghargaan positif yang bersyarat (conditional positive regard) pada orang lain. Dimana mereka cenderung akan mencela diri, menghindari tingkah laku yang dicela, merasa bersalah dan tidak berharga.

Kedua temuan diatas dapat dikaitkan dengan pemikiran Poerwandari (dalam Mayasari, 2005) bahwa kondisi masyarakat patriarki di Indonesia dan banyak negara lain yang cenderung mengatribusikan karakteristik positif dan menguntungkan seperti rasional, prestatif, peran sebagai kepala keluarga, dan pengambil keputusan pada laki-laki, serta karakteristik negatif dan tidak menguntungkan seperti pasif, tidak mampu mengambil keputusan, pelengkap, menjadi pihak yang diatur, dan memenuhi kepentingan laki-laki pada perempuan. Hal ini disebabkan konteks sosial masyarakat Indonesia yang didominasi masyarakat patriarki dengan pandangan androsentris (mengacu pada laki-laki sebagai standar), dimana stereotip maskulin diunggulkan sebagai standar tunggal "manusia" (Unger \& Crawford, 2003).

Sementara pada dua karakteristik konselor lainnya, tingginya karakteristik empathy dan congruence pada kelompok jender

Shinta Mayasari, Program Studi Bimbingan Konseling Fakultas Keguruan dan Ilmu Pendidikan Universitas Lampung. Email: shintapsy@yahoo.com 


\section{KARAKTERISTIK KONSELOR PADA CALON KONSELOR BERDASARKAN KELOMPOK GENDER}

mahasiswa perempuan justru berbanding terbalik dengan rendahnya dua karakteristik ini pada kelompok jender laki-laki. Menurut Rogers (2017), self concept (konsep diri) dan perkembangan kepribadian individu terbentuk dari pengalaman yang berhubungan dengan aku dan membedakan aku dari yang bukan aku. Konsep diri ini terbagi menjadi dua yaitu konsep diri real dan konsep diri ideal. Untuk menunjukkan apakah kedua konsep diri tersebut sesuai atau tidak, Rogers mengenalkan konsep incongruence yaitu ketidakcocokan antara self yang dirasakan dalam pengalaman aktual disertai pertentangan dan kekacauan batin. Sementara congruence berarti situasi dimana pengalaman diri diungkapkan dengan seksama dalam sebuah konsep diri yang utuh, integral, dan sejati.

Pada kelompok jender laki-laki, sangat rendahnya congruence mengindikasikan adanya perasaan gelisah akibat adanya ancaman yang bersumber dari realitas terhadap konsep diri. Tuntutan masyarakat pada peran jender laki-laki yang mensosialisasikan mereka untuk menjadi kuat, ulet, agresif, mandiri, berani mengambil resiko dan mau berjuang mempertahankan kepercayaannya (Baron \& Byrne, 2006). Asumsi stereotipikal dari orang lain mendorong individu untuk bertingkah laku sesuai stereotip. Stereotip juga memotivasi seseorang untuk bertingkah laku sesuai standar peran jender yang dipercaya masyarakat untuk dijalankan, dan menekan perilaku yang tidak sesuai dengan standar tersebut. Proses penekanan perilaku ini dapat menjadi sumber ancaman yang memicu kegelisahan bagi kelompok jender laki-laki.

Sementara pada kelompok jender perempuan, sebagian responden yaitu sebesar $47.1 \%$ memiliki karakteristik congruence sebagai karakteristik yang dominan ada pada diri mereka. Bila dikaitkan dengan proses sosialisasi jender selama masa pengasuhan, umumnya masyarakat memiliki perbedaan kecenderungan dalam mensosialisasikan peran jender terhadap perempuan dan laki-laki. Lakilaki cenderung memperoleh sosialisasi jender yang lebih ketat sementara perempuan lebih diberi "kelonggaran" dalam bertingkah laku. Sedari kecil anak laki-laki lebih ketat memperoleh sosialisasi jender dibandingkan dengan anak perempuan (Papalia, Olds, \& Feldman, 2007). Pada umumnya, pelanggaran terhadap stereotip maskulin memang lebih sukar diterima daripada pelanggaran pada stereotip feminin (Unger \& Crawford, 2003). Hal ini terlihat pada lebih diterimanya perempuan berpenampilan tomboy dibandingkan dengan laki-laki yang berpenampilan kemayu.

Pada karakteristik empathy, mayoritas kelompok jender perempuan yaitu sebesar $50 \%$ memiliki karakteristik ini sebagai karakteristik yang dominan pada dirinya. Sementara pada kelompok jender laki-laki, hanya 20,6\% yang menganggap karakteristik ini sebagai karakteristik konselor yang mendominasi kepribadiannya. Menurut Viorensika dan Suleeman (2013) perbedaan karakteristik empati antara responden perempuan dan lakilaki dapat terjadi karena perempuan dianggap

Shinta Mayasari, Program Studi Bimbingan Konseling Fakultas Keguruan dan Ilmu Pendidikan Universitas Lampung. Email: shintapsy@yahoo.com 


\section{KARAKTERISTIK KONSELOR PADA CALON KONSELOR BERDASARKAN KELOMPOK GENDER}

lebih memiliki sifat nurturance dan memiliki orientasi interpersonal jika dibandingkan oleh laki-laki sehingga berdampak pada tingkat empati yang dimiliki. Selain stereotip ini, ternyata juga terdapat beberapa penelitian yang menyatakan hal serupa. Marcus dalam penelitiannya menemukan bahwa anak perempuan lebih empatik dalam merespon secara verbal mengenai keadaan distress orang lain (dalam Viorensika dan Suleeman, 2013). Perempuan dianggap lembut, penuh kasih sayang, hangat, peka, penuh pengertian dan mencintai anak-anak, bertingkah laku keibuan terhadap anak yang lebih kecil, peduli pada orang lain dan kebutuhan-kebutuhan orang lain (Baron \& Byrne, 2006). Kemudian penelitian yang dilakukan oleh Beck (dalam Mayasari, 2005) juga menemukan bahwa terdapat perbedaan antara perempuan dan laki-laki mengenai orientasi eksternal dan internal. Perempuan lebih berorientasi eksternal (orientasi pada orang lain), sedangkan laki-laki lebih berorientasi internal (orientasi pada diri sendiri).

\section{SIMPULAN DAN SARAN}

Berdasarkan analisis dan interpretasi terhadap hasil penelitian diperoleh kesimpulan bahwa terdapat perbedaan yang signifikan antara karakteristik konselor pada mahasiswa laki-laki dan perempuan. Sebagian besar mahasiswa laki-laki memiliki karakteristik unconditional positive regard yang dominan pada dirinya sedangkan sebagian mahasiswa perempuan memiliki karakteristik empathy yang dominan pada dirinya, dan sebagian lainnya (dalam jumlah yang kurang lebih sama) memiliki karakteristik congruence. Hasil penelitian dapat menjadi bahan acuan dalam program pengembangan pendidikan dan pelatihan karakteristik konselor, yaitu karakteristik congruence lebih dibutuhkan untuk mahasiswa laki-laki, sedangkan karakteristik unconditional positive regard lebih dibutuhkan untuk mahasiswa perempuan. Penelitian selanjutnya diharapkan dapat memperbesar jumlah dan heterogenitas sampel. Selain itu, tambahan data kualitatif melalui wawancara dapat digunakan untuk memperdalam pembahasan pada hasil penelitian.

\section{DAFTAR PUSTAKA}

Anastasi, A., \& Urbina, S. (1997). Psychological testing. Prentice Hall/Pearson Education.

Azwar, S. (2014). Penyusunan Skala Psikologi. Yogyakarta: Pustaka Pelajar.

Azwar, S. (2015). Dasar-dasar Psikometri. Yogyakarta: Pustaka Pelajar.

Baron, R. A., Byrne, D., \& Branscombe, N. R. (2006). Social psychology, 11/E. Aufl, Boston.

Crocker, L., \& Algina, J. (2008). Introduction to classical and modern test theory Mason. $\mathrm{OH}$ : Cengage Learning.

Corsini, R. J., \& Wedding, D. (2010). Current Psychotherapies Belmont: Brooks.

Kerlinger, F. N. (1992). Asas-asas Penelitian Behavioral diterjemahkan oleh: Landung $\mathrm{R}$. Simatupang.

Shinta Mayasari, Program Studi Bimbingan Konseling Fakultas Keguruan dan Ilmu Pendidikan Universitas Lampung. Email: shintapsy@yahoo.com 


\section{KARAKTERISTIK KONSELOR PADA CALON KONSELOR BERDASARKAN KELOMPOK GENDER}

Lesmana, J. M. (2005). Dasar-dasar konseling. Jakarta: Fakultas Psikologi UI.

Mayasari, S. (2013). PERSEPSI CALON AYAH TERHADAP PERAN JENDER ANAK. ALIBKIN (Jurnal Bimbingan Konseling), 2(2).

Mayasari, S. (2013). Prosiding: Construction of Psychological Instrument for Measuring Counselors' Characteristics. International Teacher Education Conference.

Papalia, D. E., Olds, S. W., \& Feldman, R. D. (2007). Human development. McGraw-Hill.

Peraturan Menteri Pendidikan Nasional Republik Indonesia Nomor 27. (2008). Standar Kualifikasi Akademik dan Kompetensi Konselor.
Rogers, C.R. (2007). Counseling and Psychotherapy. US: Rogers Press.

Rogers, C.R. (2017). On Becoming a Person. A Therapist's View of Psychotherapy. Connecticut: Tantor Media.

Tim Peneliti Fakultas Psikologi Universitas Indonesia. (2016). Pengembangan Sistem Perekrutan Bintara Polri. Jakarta: Fakultas Psikologi Universitas Indonesia.

Crawford, M., \& Unger, R. (2003). Women and gender: A feminist perspective. McGrawHill.

Viorensika, S. \& Suleeman, J. (2013). Skripsi: Gambaran Empati pada Mahasiswa Psikologi Jenjang Sarjana. Universitas Indonesia.

Shinta Mayasari, Program Studi Bimbingan Konseling Fakultas Keguruan dan Ilmu Pendidikan Universitas Lampung. Email: shintapsy@yahoo.com 